incidence of the $\mathrm{X}$-ray beam produced any steady variation from equality in the two electron streams to the two anodes of the valve. No change was detected, although the galvanometer was competent to show a change of 0.05 per cent of the anode electroncurrents to the grids. Alitan Ferguson.

\section{Archæology of Eastern Colorado}

THE archæological survey of eastern Colorado carried out in the summer of 1930 by the University of Denver and the Colorado Museum of Natural History, under the direction of Dr. E. B. Renaud, with the assistance of a subsidy from the Smithsonian Institution, is the first systematic archæological work undertaken in that area, and links up the exploration of south-west Colorado on one side, and of Nebraska and States east on the other. Ten thousand miles were covered in ten weeks. A large number of surface finds were collected, but no excavation was possible in the time. The report of Dr. Renaud and his assistants (published by the University of Denver, Anthropological Department) states that few important sites were left unvisited, and the collections and notes, while not exhaustive, are fairly representative of the Indian culture of Colorado.

The area of closest settlement is in the north-west, in Larimer County, with thirty-eight sites. The contiguous counties, extending from the Rocky Mountains to the States of Nebraska and Kansas without a break, form a vast central group separated by a trough from the smaller and isolated north-west group.

The camp site is the most common (247). Here flaked artefacts and chips are fairly well grouped. Old fireplaces and tipi-rings-stone circles, on which the skins rested, marking the base of the tent-are the most certain criterion of a camp site. An unexpected number of the grinding-stones known as mano, or hand-stone, were found. The mano is smaller in the pueblo area. Pottery, previously accounted unknown or rare in the western plains, was recorded on fifty-five sites. Fifty-two workshop sites and fifteen rock-shelters were visited. Petroglyphs, rarely painted and most commonly pecked, were found on fourteen sites. Dr. Renaud has made a careful study of the stone implements, comparing them exhaustively with those of the stone age of Europe and other parts of America. The greater number are non-palæolithic, next in importance being Mousterian-like points, scrapers, and flakes.

In 1931, according to a communication we have received from the Department of Anthropology in the University of Denver, the expedition covered the archæologically rich area known as the "Spanish Diggings" in the neighbourhood of Cheyenne and Larimer. About two hundred Indian sites were visited and recorded, and a large number of artefacts were collected. The pictographs were fewer in number than was expected. Pottery was found on a number of sites, and a number of camps showed tipi-rings. The expedition was particularly impressed by the resemblance of old quarries, from which red chert, yellow jasper, and quartzite have been obtained, to the prehistoric quarries of western Europe, except for the fact that the latter had yielded flint. The relative age of these quarries is being investigated by the examination of the growth of lichen. A rapid excursion was made to north-east Wyoming, archæologically a much less interesting area; but it is anticipated that western Wyoming, when its turn comes for exploration, will yield interesting remains, especially in the form of pictographs.

$$
\text { No. 3252, VoL. 129] }
$$

\section{University and Educational Intelligence}

BIRMINGHam. - In his report to the annual meeting of the Court of Governors held on Feb. 25, the vice-chancellor and principal, Sir Charles Grant Robertson, gives the figures for the number of students. The total for the past session was 1890, which approaches the maximum reached in the "boom" period after the War. The new entries for the present session also show a marked increase. The postponement for a year (on account of national financial stringency) of the building of the new Hospital Centre and Medical School is a matter of grave concern, in view of the increasing congestion of the present buildings.

CAmbridGe.-A report of the Syndicate on the Scott Polar Research Institute recommends that steps be taken to proceed with the erection of a polar research institute on the Lensfield site. The generous gift of $£ 4000$ by the trustees of the Pilgrim Fund last year has now made up the capital of the building fund to $£ 12,000$, which is considered sufficient to provide for the cost, equipment, and maintenance of the institute which the Syndicate has in view. The financial board, while raising no objection to the recommendations, has expressed the hope that every effort will be made to increase the endowment of the institute.

London.-Dr. G. F. J. Temple, at present reader in mathematics at the Imperial College, Royal College of Science, has been appointed to the chair of mathematics at King's College, as from Aug. 1.

The William Julius Mickle fellowship for 1932 has been awarded to Dr. Philip Eggleton, for his research on the labile compounds of phosphorus in muscle.

There will be an election to Beit fellowships for scientific research in July next. Applications, upon a form supplied upon request, must be received by April 12 by the Rector, Imperial College of Science and Technology, South Kensington, S.W.7.

THE annual examinations for a Faraday scholarship of eighty guineas per annum, tenable for two years in the Faraday House Electrical Engineering College and one year in a manufacturing works, and for a Maxwell scholarship of sixty guineas per annum, tenable for two years in the College and one year in a works, will be held at Faraday House on April 5-7. Further particulars may be obtained from the Registrar, Faraday House Electrical Engineering College, 62-70 Southampton Row, W.C.1.

THE Rockefeller Foundation's disbursements in 1930 amounted, exclusive of administration expenses, to nearly fifteen million dollars, of which universities and other educational institutions received more than six millions, research institutions and organisations more than two millions, whilst public health work absorbed nearly three, and fellowships and grants-inaid more than one million. The field of the Foundation's activities embraces, in addition to its International Health Division in which expenditure since 1913 has amounted to 42 million dollars, work in the medical sciences, natural sciences, social sciences, and the humanities. In the International Health Division particular emphasis has in recent years been laid on field work, including the gathering of knowledge about widespread maladies such as hook-worm, malaria, pellagra, yellow fever, tuberculosis, and the common cold. All results of researches by members of the field staff of the Foundation or by persons working under its auspices are published (to the number of 57 in 1930) 
in the medical journals. International Health Division fellowships are given to graduates in medicine of high professional standing and assured of positions in the public health services of their own countries. In 1930,173 such fellowships were held by natives of 33 countries, including the United States and its dependencies (52), China (18), Canada (12), Italy (12), other European countries (47), Brazil (8), India (8). In addition, the Foundation supported 102 fellowships in medicine for the supplementary training of young graduate physicians, from 35 countries, in preparation for definite positions in research or teaching. Among enterprises aided by the Foundation are an institute of experimental biology in Copenhagen, an institute of cell physiology in the Kaiser Wilhelm Institute of Biology, and the Kaiser Wilhelm Institute for Brain Research.

\section{Calendar of Geographical Exploration}

\section{March 2, I705.-Coast of Northern Australia}

Maarten van Delft sailed from Timor and surveyed the coasts of Melville Island and of the Coburg Peninsula, thus supplementing Tasman's chart of the region. One of the vessels penetrated some distance into Dundas Strait.

\section{March 4, 1519.-Cortes in Mexico}

Hernando Cortes landed in Mexico. The discovery of Mexico by Juan Grijalva led Velasquez to entrust to Cortes the exploration and conquest of the country. Starting from the coastal regions near the modern Vera Cruz, Cortes marched to the city of Mexico, sending a party to explore the snow-clad Popocatepetl en route. The city was captured in August 1521, and Cortes sent out exploratory parties in all directions, Alvarado making some conquests in Guatemala. Cristobal de Olid, who had been ordered to reach Cuba via Honduras, reached the southern shores of the gulf, but mutinied against Cortes. The latter left Mexico in 1524 and marched through Tabasco to the Gulf of Honduras. There he again sent out exploring parties from the town now known as Puerto Cortes and later from Trujillo.

\section{March 4, r79r.--Islands of the Pacific}

Capt. Edwards, in the Pandora, sighted Easter Island on a voyage undertaken partly in search of the mutineers from Bligh's essel. These men had apparently appreciated life in the South Sea islands so much that they wished to remain. Some of them successfully settled in Pitcairn Island. Edwards discovered some small islands in the Low Archipelago, and later, in his search for the mutineers, covered much of the Pacific not usually touched in trading voyages, thus many previously unknown islands were charted. In the neighbourhood of Torres Strait the Pandora was wrecked; some of the crew weredrowned, but others escaped in the boats and after terrible hardships reached Timor.

\section{March 4, I905.-Charcot Land}

Dr. Jean Charcot in the Francais arrived in Puerto Madrina, Argentina. Charcot had planned a voyage to the Antaretic to rescue Dr. O. Nordenskjöld, but this had been effected by an Argentine vessel. Charcot then, in the course of two summer cruises, surveyed parts of the west coast of Graham Land and reached Alexander I. Land. His vessel was delayed by ice and anxiety was felt about its possible fate, but in spite of severe damage it escaped. In 1908-10, Chareot returned to the Antarctic and discovered the land which now bears his name.

$$
\text { No. 3252, VoL. 129] }
$$

\section{Societies and Academies}

\section{LONDON}

Royal Society, Feb. 18.-D'Arcy W. Thompson : The geometry of the siliceous skeletons of the Radiolaria. The figures of equilibrium and minimal area which are assumed by soap-films in Plateau's experiments have proved helpful in explaining the configurations of various cells and simple tissues in plants and animals. Among the most curious and anomalous of cell-forms are those of certain Radiolaria. In some of these the skeleton resembles a minute spiked helmet with three curved lappets or straps below. Even such an anomalous configuration as this may be precisely imitated or reproduced by an artificial system of liquid films.--H. W. S. Massey and C. B. O. Mohr: The collision of slow electrons with atoms (1). The theory has been developed in which the zero approximation is not a plane wave but the wave representing the motion of the electron in the static field of the atom concerned. Exchange does not become very important until voltages lower than those obtained on Born's theory using the plane wave as first approximation. At lower voltages, strong interference effects occur between the incident and exchanged electron waves, giving peculiar angular distributions of the scattered electrons. These effects are observed experimentally. -H. C. Webster : The artificial production of nuclear $\gamma$-radiation. The production of nuclear $\gamma$-radiation by bombardment with $\alpha$-particles has been observed for the elements $\mathrm{Li}, \mathrm{Be}, \mathrm{B}, \mathrm{F}, \mathrm{Na}, \mathrm{Mg}, \mathrm{Al}$. Negative results were obtained with $\mathrm{H}, \mathrm{C}, \mathrm{N}, \mathrm{Ni}, \mathrm{Cu}, \mathrm{Sn}$. The absolute efficiencies of production of the various radiations range from about 0.5 quanta per million $\alpha$-particles for magnesium to about 30 quanta for beryllium. In addition, the way in which the efficiency of production varies with the residual range of the a-particles was investigated. The processes probably responsible for the radiations are discussed : some appear to be due to the capture of an $\alpha$-particle by a nucleus without proton emission, others are probably due to a secondary process following proton emission, others may arise from inelastic collisions without capture.

Geological Society, Dec. 16.-J. E. Richey: The Tertiary ring complex of Slieve Gullion (Ireland) This complex lies west of the Mourne Mountains and north-west of the Carlingford Peninsula. Topographically, it consists of a ring of curving ridges and hills, 7 miles in diameter, which is bisected by a mountainous belt extending to the north-west. The ring and the north-west belt mark the outcrops of a very simple ring-dyke complex and later Tertiary plutonics. The ring complex forms a complete ring, exeept to the south-west, where it is broken through by the north-west belt. The almost exact coincidence of the ring-fissure with the margin of the westerm portion of the Nowry granite is perhaps its most remarkable feature. The constituent rocks of the ring are given.

\section{Paris}

Academy of Sciences, Jan. 11.-E. Jouguet Remarks on a theorem of Hugoniot relating to the flow of fluids.-Maurice Hamy: A property of the equation obtained by equating to zero the distance of two planets, $P, P_{1}$, which do not meet at real points.-Paul Qvale: Remarks on Thiele's semiinvariants.--Georges Bouligand: Various problems of infinitesimal geometry.-N. Aronszajn: The decomposition of uniform functions.-W. Wrlicz : Some theorems on orthogonal developments.-René de Possel: Étoilées functions and ensembles of the 